\title{
ВОЗМОЖНОСТИ МЕТОДА УФ-ВИД СПЕКТРОФОТОМЕТРИИ ДЛЯ АНАЛИЗА НОВЫХ МАТЕРИАЛОВ И НАНОСИСТЕМ
}

\author{
Ларина Т.В.
}

\author{
ФГБУН ФИЦ Институт катализа им. Г. К. Борескова СО РАН, Новосибирск, Россия
} viktanlar@mail.ru; larina@catalysis.ru

DOI: 10.26902/ASFE-11_64

Метод УФ-Вид спектрофотометрии широко используется для анализа физикохимических, структурных и оптических свойств материалов различного назначения, полученных химическими и физическими способами.

Метод УФ-Вид спектрофотометрии - один из немногих неразрушительных физикохимических методов анализа, который позволяет работать с исследуемым твердым материалом, не прибегая к различным их пробоподготовкам, что делает данный метод экспрессным и более доступным для рутинного анализа образцов.

Метод УФ-Вид спектрофотометрии является количественным методом для анализа примесей в пробах в виде растворов или монокристаллов. Как качественный метод анализа он хорошо подходит для исследования проб в виде твердого тела, например, металлических пластин, порошков, таблеток или пыли.

Метод УФ-Вид спектрофотометрии позволяет исследовать состояние $d$ элементов, как на поверхности массивного образца, так и в его объеме. Чаще всего данный метод используют для исследования электронного состояния $d$ элементов в истинных растворах, а также для определения их степени окисления и координационного числа в комплексах, массивных и нанесенных кислородсодержащих системах. Данный метод широко применяется для установления природы взаимодействия нанесенных или примесных $d$ элементов между собой как в условиях реальных растворов, так и в твердых пробах, например, в кислородсодержащих матрицах - всевозможных наносистемах и новых материалах различного назначения.

Исследование электронного состояния и координационного окружения $d$ катионов, как модификаторов кислородсодержащих систем, является очень важным для катализа и других областей науки, например, твердотельной электроники, энергоемких материалов, твердотельной керамики и других строительных материалов. Особенно интересным является изучение методом УФ-Вид спектрофотометрии в режиме диффузного отражения электронного состояния $d$ элементов в составе гетерогенных катализаторов, поскольку компоненты катализаторов почти всегда находятся в рентгеноаморфном или высокодисперсном состояниях, и имеют малые концентрации модифицирующих компонент. При данных условиях другие физические методы исследования являются малоинформативными. При этом при регистрации спектра отражения не наблюдается какихлибо воздействий на образец и изменения его физико-химических свойств во время съемки, поскольку энергия обоих источников излучения сравнительно мала, а глубина проникновения луча при анализе образца в виде порошка или гранул составляет порядка миллиметра.

Метод УФ-Вид спектрофотометрии идеально подходит для исследования образцов на всех стадиях их приготовления: от исходных растворов, через все промежуточные соединения, до конечного продукта - материалов различного назначения, что является наиболее экономически выгодным решением при организации Научно-исследовательских лабораторий для комплексного анализа при управлении свойствами и контроле качества выпускаемой продукции на Промышленных предприятиях.

Работа выполнена при финансовой поддержке Министерства науки и высшего образования РФ в рамках государственного задания Института катализа СО РАН (проект АAAA-A21-121011890074-4).

Исследования методом УФ-Вид спектроскопии выполнень с использованием оборудования Центра коллективного пользования «Национальный цеентр исследования катализаторов». 